The Geographical Journal of Nepal

Vol. 15: 1-22, 2022

DOI: https://doi.org/10.3126/gjn.v15i01.42883

Central Department of Geography,

Tribhuvan University, Kathmandu, Nepal

\title{
Drivers of changing crops and cropping patterns in the different elevation zones of middle mountain, Nepal
}

\author{
Payaswini Ghimire ${ }^{1}$, Prem Sagar Chapagain ${ }^{1 *}$, Jianzhong Yan ${ }^{2}$, \\ Xian Cheng ${ }^{2}$, Linshan Liu ${ }^{3}$, Yili Zhang ${ }^{3}$ \\ ${ }^{1}$ Central Department of Geography, Tribhuvan University, Kathmandu, Nepal \\ ${ }^{2}$ Colleges of Resource and Environment, South West University, Chongqing, China \\ ${ }^{3}$ Institutes of Geographical Sciences and Natural Resources Research, Beijing, China \\ "Corresponding author: ps.chapagain@gmail.com
}

Received: 19 October, 2021; Accepted: 10 November, 2021; Published: March, 2022

\begin{abstract}
Studies on rural livelihood and agriculture patterns from different parts of Nepal have mentioned the introduction of new crops from different pocket areas of the country primarily resulted due to climate change and market development. However, these studies have lacked scholarship on how the changes occur in rural areas and how rural households have adopted the changes are least focused. Based on the field surveys using questionnaires, interviews, FGD, analysis of climate data, and map data, this paper aims to fulfill the aforementioned gap based on the study from three elevation zones. It shows a wider adoption of different new crops and vegetables which are varied by elevation zones and by the cultural groups living there. The detailed analysis of various events and underlying processes concludes that out-migration and off-farm employment, infrastructure development and increasing connectivity, climate change, access to market, and changing food habits are the major drivers of the changes. These drivers began to play their roles at different times, and different scales in different zones, and finally their complex interplay resulted changes in the rural agricultural landscape.
\end{abstract}

Key words: Crops, elevation zone, drivers, climate change, events and processes, agricultural landscape 


\section{Introduction}

Nepal lies in the central Himalayas. Within average $190 \mathrm{~km}$ north-south width, the country has three major ecological regions - High Mountain, Middle Hill, and Tarai and micro-regions within each zone (LRMP, 1986). The altitudinal variation, ranging from 60 meters to the top of the world, is very vast which causes vertical differentiation of climate and vegetation types (Barry, 2008) and has exhibited various production possibilities (Guillet, 1983). Importantly, differences in socio-economic and cultural practices give rise to diverse crop cultivation across the country (Upadhaya and Joshi, 2003).

Agricultural activities cover about 60 percent of the total employment and contribute about 27 percent to the national GDP (MoF, 2019). Nepalese agriculture is primarily subsistence, although changes have been gradually taking place towards commercialization with the introduction of vegetables, fruits, and cash crops in certain pocket areas at different parts of the country mainly due to the interplay of climate, and markets which are outside farmers' control (Aase and Chapagain, 2005; Chapagain, 2006; Lama and Devkota, 2009; Yang, Khanal, Koirala and Nepal, 2014; Dahal et al., 2018; Dhakal, Sedhain and Dhakal, 2016; Budathoki, 2017; ICIMOD, 2012; Manandhar, Schmidt-Vogt, Perret and Kazama, 2011). But these factors have directly affected farmers' decisions regarding the types of crops to be cultivated and the timing of cropping (Martin, martin-Clouaire, and Duru, 2013). Importantly, recent climate change in Nepal has resulted in inconsistent weather patterns (DHM, 2017; PAN, 2009). It has resulted in increasing temperature and inconsistency in volume, and intensity of rainfall that has directly impacted the agricultural practices (Bhatta, Helmuth van Oort, Stork, and Baral, 2015; Chapagain, 2006; Dahal et al., 2018; Raut, Sitaula, Aune and Bajracharya, 2011) particularly shifted the cropping calendar (Dahal et al., 2018; Aase, Chapagain and Tiwari, 2013; Bhatta, Helmuth van Oort, Stork and Baral, 2015; Yang, Khanal, Koirala and Nepal, 2014; Manandhar, Schmidt-Vogt, Perret and Kazama, 2011). In addition to these factors, demographic, and technological changes can have an important role in agricultural transformation (Rao and Parwez, 2005; Ray, 2007; Aydinalp and Cresser, 2008; Khanal and Watanabe, 2006). Besides socio-economic dynamics, cultural practices have also affected the agriculture system in Nepal (Paudel and Shaw, 2016; Dhakal, Sedhain and Dhakal, 2016). Despite these studies, there is still a lack of knowledge on what changes have been taking place in crops and cropping patterns and how rural households have adopted these changes in the face of the complex interplay of various factors and processes. Hence, this paper aims to address these two issues in particular from a micro-level analysis focusing on the north-south extended river basin of central Nepal. 


\section{The study area}

The study area, Marbu village, lies in Gaurishankar Rural Municipality of Dolakha district, about 170 kilometers northeast of Kathmandu, Nepal. It is located between $86^{\circ}$ $16^{\prime} 50^{\prime \prime} \mathrm{E}$ to $86^{\circ} 17^{\prime} 30^{\prime \prime} \mathrm{E}$ and $27^{\circ} 45^{\prime} 40^{\prime \prime} \mathrm{N}$ to $27^{\circ} 47^{\prime} 15^{\prime \prime} \mathrm{N}$ (Figure 1). The area ranges from 1250 meters above sea level (masl) to 5000 masl. Demographically, there is high ethnic diversity with the majority of Newar and low caste groups in the valley bottom, indigenous Gurung in the mid-slope, and Sherpa in the upper part of the village. From an economic standpoint, almost all households are involved in agriculture activities to various extents. The area has been recently connected to the local market and district headquarters. There is regular public bus service from the village to Kathmandu except during monsoon season. A few shops, schools, and municipality ward offices are located in the main village.

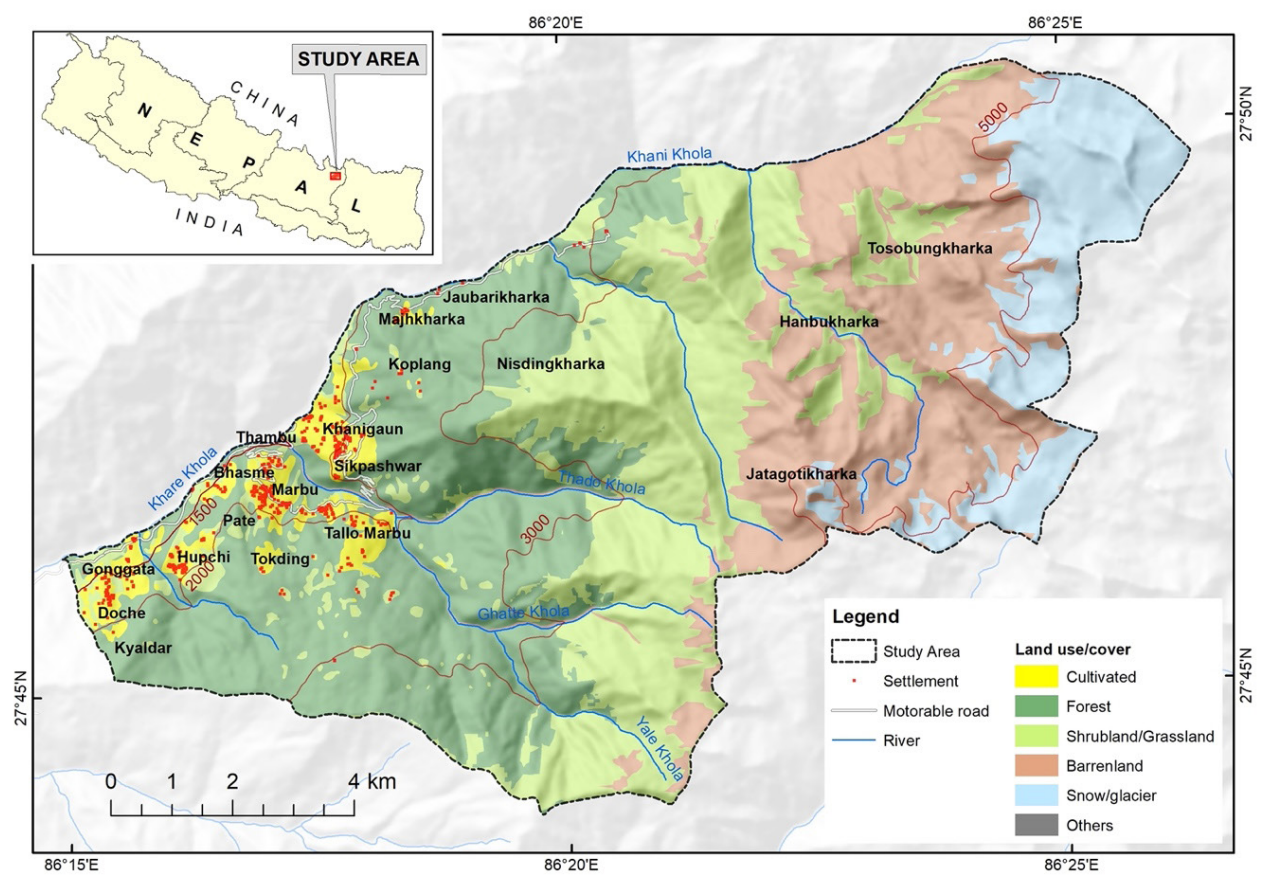

Figure 1: Study area (Marbu village, Dolakha)

\section{Methods and materials}

For data collection and analysis, the study area is divided into three zones with respect to altitude i.e., below 1500 masl, 1500 to 2000 masl, and above 2000 masl. The division 
is based on crops and cropping patterns, differences in the social groups, microclimatic variation, and landform characteristics. The low land has valley bottom with some flat land with a gentle slope and there is a terraced slope in the midland and a mix of terraced and un-terraced grazing land at the higher elevation.

\section{Data collection and analysis}

This paper is based on both primary and secondary data. Primary data was collected through field surveys using household questionnaire, focus group discussion, key informants' interviews, and transect walk. Household surveys were conducted through Kobo Toolbox utilizing semi-structured questionnaires. The Kobo toolbox is an opensource tools for the collection of field data. It is developed by the Harvard Humanitarian Initiative (https:/www.kobotoolbox.org) which is available online. The questionnaires covered socio-economic characteristics, land types, landholding situation, livestock, labor types and gender division of work, perception about climate change, crops and cropping pattern over the last 30 to 40 years of time and the reasons for changing crops. A total of 60 households ( 20 in each elevation zone) which is about 12 percent of total 526 households (Information from Gaurishankar rural municipality), was selected for the household survey.

Analysis of the changes in land use/cover between 1996 and 2019 was also done. The 1996 land use/cover types were captured from the topographic map of 1:25000 and 1:50000 scale and compared with the land use/cover of 2019 prepared from the latest Google Earth image and from Cartosat Image (25m resolution, 2016) available from the Irrigation Department, Government of Nepal. A detailed analysis of changes in agricultural land was carried out using ArcGIS (10.4). It was further verified with key informants during the field survey. An in-depth interview was held with six keyinformants (two from each zone) and discussed the various events and processes, and their role in the selection of crops and cropping calendar, changes in size and types of livestock, and the reasons behind such changes.

One focus group discussion (FGD) was held with a group comprising the farmers from the three micro-regions, school teachers, social workers, local agro-businessmen, and local hotel/restaurant owners. The focus of the discussion was about the changes in crops and cropping patterns over the last 30/40 years and the associated motivation. Furthermore, discussions regarding climate change, labor, manure/fertilizer, local economy, market accessibility, societal changes, and how these factors have influenced their preferences for crop selection, and cultivation were also discussed with the group. During the FGD and KII, participants were first asked about the events and then their 
repercussions on the local farming system at the village and it was analyzed together with the household survey data.

Changes in rainfall and temperature of the village have analyzed based on available climate data of the last 30 years from the nearest agro-metro station (Jiri station), collected through the Department of Hydrology and Meteorology, Government of Nepal. Household survey data on climate change perception has also been analyzed and presented with reference to the observe data. The collected socio-economic and other data were processed in MS-Excel. The information from the interviews and FGD was compiled, categorized and then descriptive analysis was done

\section{Results and discussion}

\section{Demography and landholding situation}

The vertical distribution pattern of resources is common in Himalayas (Guillet, 1983). This also implies in social demography that the Sherpa community settled at the uppermost part of the village while Newar, Chhetri, and blacksmith settled at the bottom of the valley whereas Gurung and Magar communities are in the mid-elevation region. About 65 percent population is in the age group of 15-64. With regard to occupation, farming is the major economic activity followed by wage labor, private service, and small business. Nearly one-third of the population has no formal schooling background while the two-thirds are either literate or have formal schooling background.

The household number of the village has increased gradually over time but the population size has decreased in the last three decades. The total number of households was 278 with a total population of 1520 (51 percent male and 49 percent female) in 1991 while the number of households was increased to 331 but the total population decreased to 1409 in the 2011 census. From 2011 to 2019, the number of households increased drastically to 526. The increment in household numbers was primarily due to the injection of monetary relief by the government, which was distributed to each household, in the aftermath of the earthquake in 2015. Consequently, many joint families separated into nuclear families that resulted in a rapid increase in the household number of the village. A detailed socio-demographic snapshot is given in Table 1. 
Table 1: Socio-economic characteristics of study village

\begin{tabular}{|c|c|c|c|}
\hline Age group & Female \% & Male \% & Total \% \\
\hline $0-14$ & 9.9 & 9.9 & 19.8 \\
\hline $15-59$ & 27.8 & 36.9 & 64.7 \\
\hline$>60$ & 7.1 & 8.3 & 15.5 \\
\hline Grand Total & 44.8 & 55.2 & 100.0 \\
\hline Education* & Female \% & Male \% & Total \% \\
\hline Illiterate & 18.5 & 12.3 & 30.9 \\
\hline Literate & 8.6 & 21.0 & 29.6 \\
\hline Primary & 12.3 & 13.2 & 25.5 \\
\hline Secondary & 3.7 & 5.3 & 9.1 \\
\hline Higher Secondary & 1.6 & 2.9 & 4.5 \\
\hline University level & 0.0 & 0.4 & 0.4 \\
\hline Grand Total & 44.9 & 55.1 & 100 \\
\hline Occupation** & Female \% & Male \% & Total \% \\
\hline Farmer & 28.9 & 17.2 & 46.1 \\
\hline Wage Labor & 1.4 & 16.7 & 18.1 \\
\hline Student & 6.5 & 7.0 & 13.5 \\
\hline Private Service & 1.4 & 7.5 & 8.9 \\
\hline Business/Shop owner & 2.3 & 1.4 & 3.7 \\
\hline Retired & 0.9 & 2.8 & 3.7 \\
\hline Govt. Service & 0.9 & 1.4 & 2.3 \\
\hline Self-employed/ professional & 0.0 & 2.3 & 2.3 \\
\hline Housewife & 0.9 & 0.0 & 0.9 \\
\hline Social worker & 0.0 & 0.5 & 0.5 \\
\hline Grand Total & 43.2 & 56.8 & 100.0 \\
\hline Absent/Present population & Female \% & Male \% & Total \% \\
\hline Absent & 4.0 & 13.9 & 17.9 \\
\hline Present & 40.9 & 41.2 & 82.1 \\
\hline Grand Total & 44.9 & 55.1 & 100.0 \\
\hline Caste/Ethnicity & Female & Male & Total \% \\
\hline Chhetri & 1.2 & 1.6 & 2.8 \\
\hline Gurung & 8.7 & 8.3 & 17.1 \\
\hline Blacksmith & 5.6 & 6.0 & 11.5 \\
\hline Magar & 6.0 & 5.2 & 11.1 \\
\hline Newar & 2.8 & 5.6 & 8.3 \\
\hline Sherpa & 19.4 & 27.4 & 46.8 \\
\hline Tamang & 1.2 & 1.2 & 2.4 \\
\hline Grand Total & 44.8 & 55.2 & 100.0 \\
\hline
\end{tabular}


From the survey, it was found that the average landholding is about 1.4 hectares per household (Table 2) which is higher than the average farm size (0.7 ha) of Nepal (CBS, 2014). Generally, most of the households of single people above 70 years, and aged parents have rented out their cultivated land.

Table 2: Landholding size by households

\begin{tabular}{crr}
\hline Land holding size (ha) & Number of households & \% Household \\
\hline$<0.5$ & 9 & 15.0 \\
$0.5-1$ & 34 & 56.7 \\
$1-1.5$ & 15 & 25.0 \\
$>1.5$ & 2 & 3.3 \\
\hline Grand Total & 60 & 100 \\
\hline
\end{tabular}

\section{Land use/cover change}

Land use/cover change has been a recent widespread phenomenon in the middle hills and mountain areas of Nepal (Khanal and Watanabe, 2006; Chapagain, 2006; Chidi, 2016; Regmi, Saha and Subedi, 2017; Chapagain, Rai and Paudel, 2018). In 1996, agricultural land had covered about 6 percent of the total area that has been declined to about 3 percent in 2019. During the period, the agricultural land has shrunk by about 53 percent. The notable change has observed from agriculture to shrub land (28\%), open field (21\%), and forest (3\%) (Table 3, Figure 2).

Table 3: Land use/cover of the study area, 1996 and 2019

\begin{tabular}{llrllrrr}
\hline SN & $\begin{array}{l}\text { Land use Type } \\
\text { (1996) }\end{array}$ & Area (ha.) & \% & $\begin{array}{l}\text { Land use } \\
\text { (2019) }\end{array}$ & Type & Area (ha.) & \% \\
\hline 1 & Cultivated & 690.5 & 6.06 & Cultivated & 328.5 & 2.88 \\
2 & Forest & 4520.5 & 39.67 & Forest & & 3751.4 & 32.90 \\
3 & Bush/grass & 1730.6 & 15.19 & Bush/Grass & 3555.5 & 31.20 \\
4 & Barren, snow & 4335.8 & 38.05 & $\begin{array}{l}\text { Barren, snow \& } \\
\text { glacier }\end{array}$ & 3644.9 & 31.99 \\
& $\&$ glacier & 117.5 & 1.03 & Others & & 114.4 & 1.00 \\
5 & Others & $\mathbf{1 1 3 9 4 . 8}$ & $\mathbf{1 0 0}$ Total & & $\mathbf{1 1 3 9 4 . 8}$ & $\mathbf{1 0 0}$ \\
\hline
\end{tabular}

Source: Topographic Map, 1996; Carto Sat /Google Earth Image, 2019

Most of the Sherpa households have abandoned their agricultural land located at a higher elevation. Lands that are distant from the home and degraded are abandoned at first but now gradually the productive land is also being abandoned. An increase in 
land abandonment resulted in forest regeneration that amplified wildlife conflict which further discouraged other farmers to continue farming.

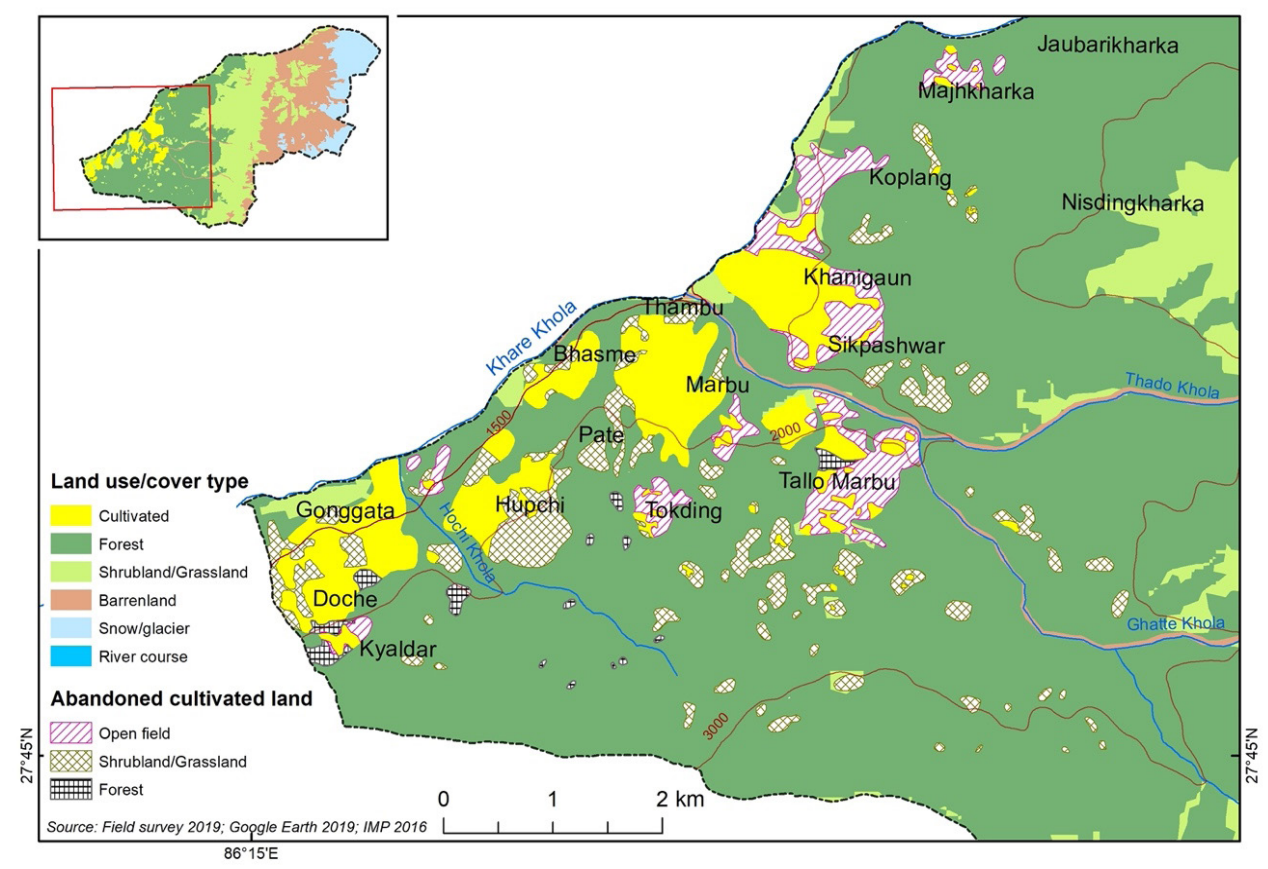

Figure 2: Agricultural land use change (1996-2019) of study area

\section{Crops and cropping calendar change}

Until 1980, only limited crops and vegetables such as potato, buckwheat, and barley were cultivated in higher elevation $(>2000)$ while maize, millet, and wheat were major crops in elevation between 1500-2000 masl. In the valley bottom, below 1500 masl, paddy, maize, and wheat were the major crops though, they also cultivated millet. Likewise, potato and broadleaf mustard in the upland and garlic, onion, chili, potato, and broadleaf mustard were the major vegetables in the midland and lowland. After 1990, the cultivation of a few crops such as buckwheat, barley, and necked barley ( $u w a)$ were almost stopped of being cultivate in upland. Not many changes have appeared in midland and low land except the introduction of many new vegetables during the last 10-15 years (Figure 3 ) though only a limited amount was for commercial purposes. 


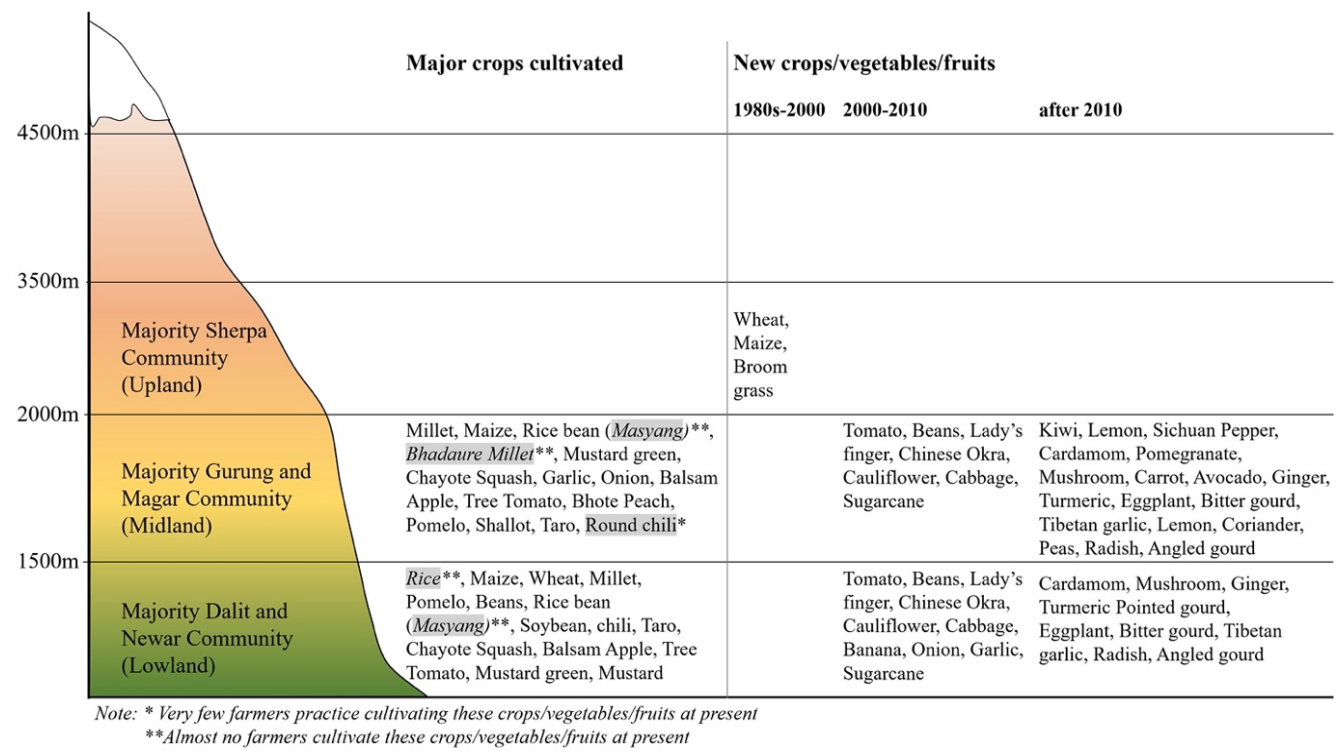

Figure 3: Major crops/vegetables/fruits by elevation zone

Consequently, with changes in crops, a major shift has been observed in the cropping calendar. As given in Figure 4, the sowing of potato has been delayed for three weeks and harvesting also delayed for a month. The major change is also observed in both upland and lowland wheat. Upland wheat sowing has been delayed for one week and harvesting has shifted about two weeks earlier. While lowland wheat sowing has being delayed about three weeks and also harvest earlier. The early harvesting is mainly due to the change in seed variety.

The cropping sequence also varies with elevation. Three crops, potato-wheatbuckwheat, are grown in two years cycle in upland while two crops maize-wheat/ millet with soybean are produced in midland and three crops, maize-millet-wheat, are grown in low land. The cropping sequence of upland before 40 years was potato-barley/ necked barley (uwa)/buckwheat. Crops like barley and buckwheat have significantly declined while cultivation of necked barley (uwa) and upland millet have almost been disappeared. The cropping sequence of midland has not been changed. Likewise, the cropping sequence of the lowland was rice/maize-millet-wheat. Rice has been almost completely abandoned by lowland farmers. 


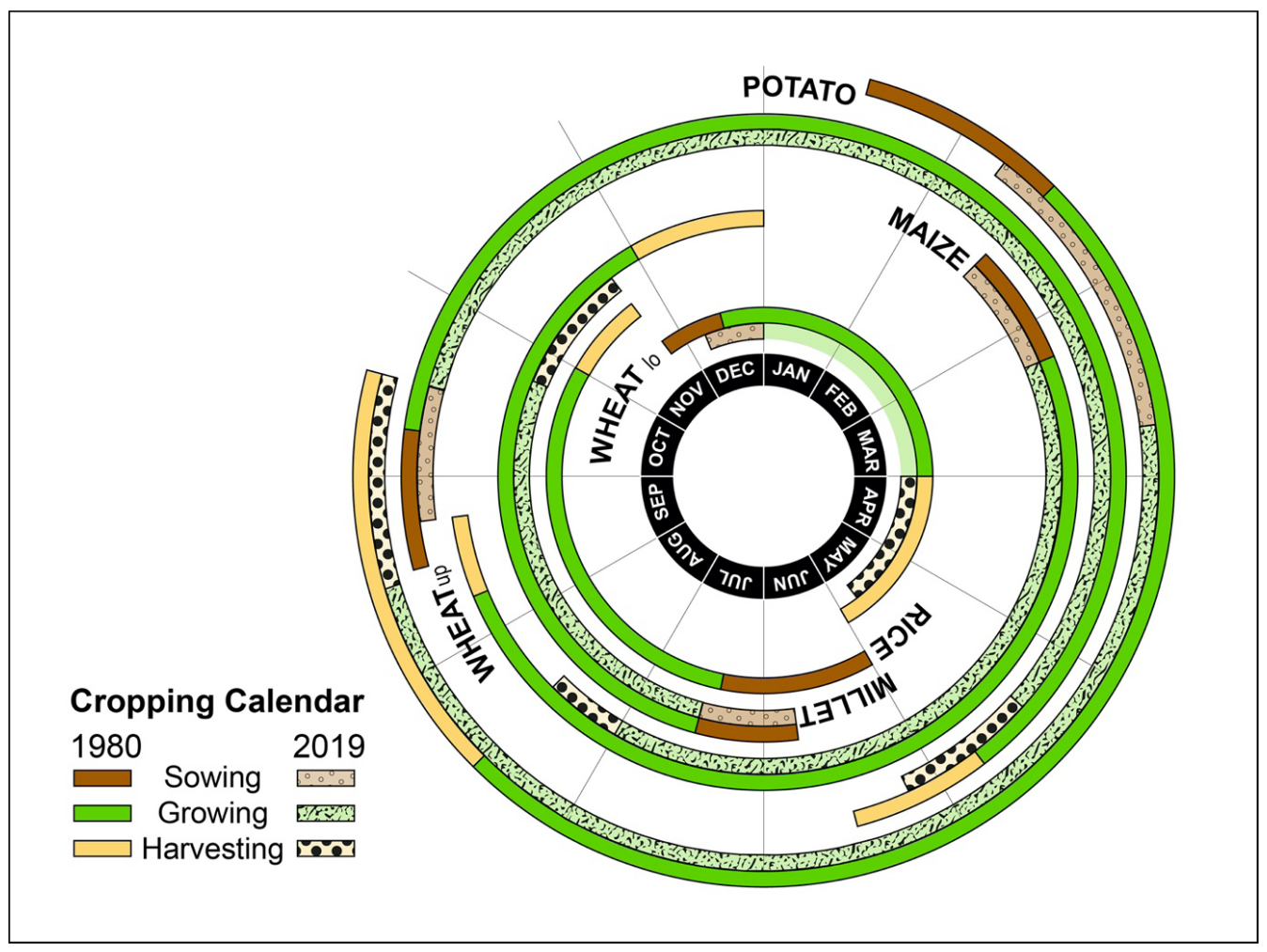

Figure 4: Past and present cropping calendar

\section{Livestock rearing}

Livestock is an integral part of mountain farming and it is also varied by elevation. The main types of livestock in the study area are yak, sheep, buffalo, cow, and goats. Out of total livestock (456), 58 percent are yak and the remaining is goat. The average number of livestock per household is 7.6. However, livestock types and numbers are varied by caste and ethnicity. For instance, Sherpa focus to rare yak, Gurung focus to sheep and buffalo, and blacksmith and Newar focus to cow and goat. The average number of livestock of Sherpa household is 8.4. It is 6.3 for Gurung and 9.2 of Magar and 7.3 of blacksmith and Newar community.

Livestock farming has undergone major changes over time. Sheep and buffalo farming has been declined but yak farming has been increased in recent years due to increasing demand for yak products like cheese and butter. Several studies have also shown that a decrease in the availability of grazing land led to the decline of sheep farming in the hills and mountains of Nepal (Bhatta, Helmuth van Oort, Stork and Baral, 2015; Tulachan, 
2000). However, there is enough grazing land in the study area. The primary reason for declining sheep farming is the lack of demand for sheep's wool for preparing local garments and also due to the attraction of young Gurung people to off-farm employment in urban areas.

\section{Drivers of changing crops and cropping pattern}

Systematic analysis of drivers of changes in the local farming system has been examined through the analysis of different events that have been taking place at different levels i.e. local, regional, and national and beyond. As given in Figure 5, the booming carpet industry, private recruitment for labor migration to the Middle East and Malaysia, Maoist insurgency, construction of road, hydropower were the major events that have differently affected the farm households over the time in the study area

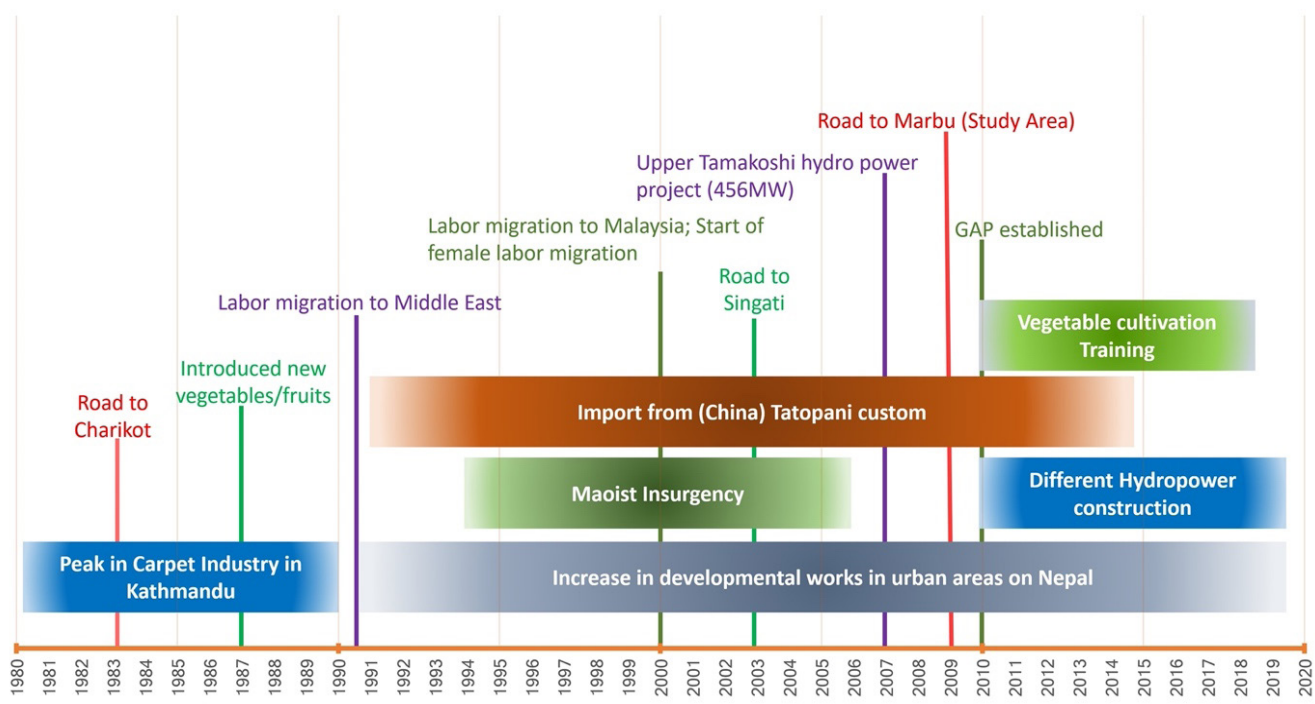

Figure 5: Development events within and outside of the study area

Although there are many activities/events taking place in the study area, these are broadly summarized as i) out-migration and off-farm employment, ii) infrastructure development and connectivity, iii) change in food habit, iv) extension services/training, vi) market development, and v) climate change. All these drivers play a significant role in bringing changes in crops and cropping patterns which are shown in Figure 6. 


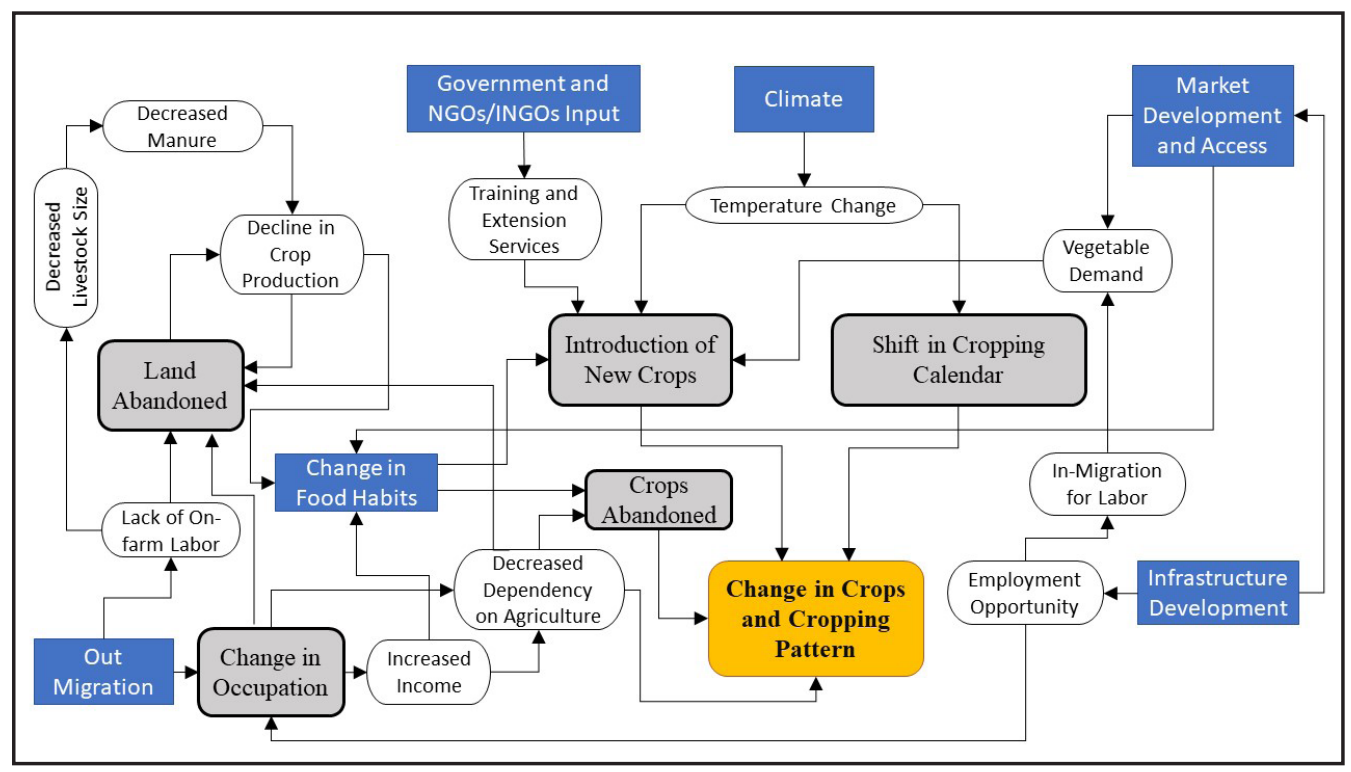

Figure 6: Drivers of change in crops and cropping patterns

\section{Out migration and off farm employment}

Out-migration is the key livelihood strategy in Nepal (Acharya and Leon-Gonzalez, 2014; Choithani, 2017) and it is one of the major drivers bringing changes in the local farming system. It was found that before the opening of foreign employment and boom of the carpet industry in Kathmandu during the 1980s, villagers used to migrate only to India for work. The flourishing carpet industry in Kathmandu attracted many young and adults from the surrounding districts. The carpet industry gradually declined after 1990. At the same time, massive urbanization in the capital city - Kathmandu, created employment opportunities in the construction sector, transportation, industry, and small businesses that resulted youth migration and agricultural labor shortage in the village. Likewise, a new wave of migration beyond India to Gulf countries and Malaysia also started during the same period. Lately, there has also been an increasing trend of female migration overseas since 2008/9 (MoLE, 2018). Dolakha was among the top ten contributors of women accessing foreign labor permits till the year 2013/14 and then the numbers gradually declined (MoLE, 2018). On top of that, females whose husbands are in Gulf countries have also migrated to district headquarters for their children's education.

In the village, one in every three households has at least one absent family member. Out of the total absent population, the majority have migrated to Kathmandu (53\%), to 
the district headquarters (7\%), and to the different parts of the country (16\%). About 13 percent were migrated to Gulf countries and India (13\%) and about 11 percent to the other countries. The major purpose was employment and escaping from the internal conflict (67\%), and children's education (20\%). Regarding the duration, 40 percent were migrated for about 1-5 years; about 35 percent for 10 years, and the remaining were for less than one year. With increasing migration out of the village to Kathmandu and foreign countries, land abandonment started as early as the 1980s and gave off cultivating many crops such as barley, buckwheat in upland, and rice bean in midland (see Figure 3). Kamal Shrestha, $(64, \mathrm{M})$ responded "...there is no one from my household to work in the field due to which most of my uplands are abandoned. My sons have migrated to Kathmandu and have started business there. They visit us twice a year but do not involve in any farm activities." Similarly, a young woman (Pemba Sherpa, 52, F) also claimed "... my daughter went to Jordan for employment last year. I am alone and cannot work in the field. After the death of my husband, most of the uplands are abandoned. My daughter sends money from Jordan, I can buy food."

Many studies also found that out-migration and off-farm income as the major drivers of land-use change which brought changes in the local farming system in Mountain and Hill regions of Nepal (Chapagain, Rai and Paudel, 2018; Ghimire and Aase, 2007; Khanal, Alam, Khanal and Regmi, 2014; Paudel, Tamang and Shrestha, 2014; Khanal and Watanabe, 2006; Chidi, 2016) and elsewhere (Jaquet, Kohler and Schwilch, 2019).

\section{Infrastructure development and increasing connectivity}

Road and hydropower projects are the major development activities taking place in the study area. As given in Figure 5 the road to district headquarter (Charikot) from Kathmandu was laid out in 1983. People started visiting Charikot for white rice. By 2008, the road connected nearby market town, Singati. Finally, the study area was connected with the roadway in 2009/10. It has enhanced mobility and people have easy access to market goods. Also, after the opening of labor migration and an increase in remittance, people had enough cash to buy foods and other supplies as the import of such items also drastically increased from 1990 in Nepal (Kafle, 2017).

The second most important infrastructure investments in the village and the nearby area were the hydropower projects. The Upper Tamakoshi hydropower project (456 MW) started in 2007 and completed in September 2021. There are 14 small and medium-sized hydro projects near the village which are about to be completed as well. These projects attracted many laborers within and outside of the village and have created the demand for many local products primarily vegetables, dairy, meat, local beer, etc. Importantly, 
these projects like in other parts of the country (Shrestha, Raut, Maung and Tieng, 2018; Dahal et al., 2018; Dahal, Nyborg, Sitaula and Bajracharya, 2009; Raut, Sitaula, Aune and Bajracharya, 2011) have also contributed to social welfare and public infrastructure development including support to different types of agricultural training that helped to introduce new crops such as cabbage, cauliflower, tomato, radish, etc.

It is not uncommon that off-farm employment opportunities led labor shortage to farm activities in Nepal ((Raut, Sitaula, Aune and Bajracharya, 2011; Raut and Sitaula, 2012; Lamichhane, Ranabhat, Adhikari and Dhakal, 2014) and other countries as well (Brown and Kennedy, 2005). Although household income increased, agricultural labor shortage has been noticed in the study area. As a result, it has decreased herd size of livestock and increased land abandonment in the study area.

\section{Climate change}

Climate change has been one of the factors in shifting the harvesting and sowing period of crops. Dolakha district is ranked as one of the most vulnerable districts to climate change especially, to drought and rainfall hazards (MoE, 2010; Sherpa, Ayadi and Pradhan, 2015). Evidence of increasing temperature and decreasing annual rainfall has observed in this district (DHM, 2017; Sherpa, Ayadi and Pradhan, 2015; PAN, 2009) where the maximum annual average temperature has increased by $1^{\circ} \mathrm{C}$ during 1980 2010 (Bhatta, Helmuth van Oort, Stork and Baral, 2015).

Figure 7 shows the temperature and rainfall scenario of the study area. Both maximum annual and minimum annual temperatures have been increased in the last 30 years. Similarly, local farmers have been already experiencing the impacts of climate change such as decline and drying up of water sprouts, more disease in plants and animals. Similar findings are reported from other Mid-hill districts of Nepal (Charmakar, 2010; Lamichhane, Ranabhat, Adhikari and Dhakal, 2014; Shreshtha and Baral, 2018; Bhatta, Helmuth van Oort, Stork and Baral, 2015; Dhakal, Sedhain and Dhakal, 2016; ICIMOD, 2012; Yang, Khanal, Koirala and Nepal, 2014; Manandhar, Schmidt-Vogt, Perret and Kazama, 2011; Lama and Devkota, 2009).

In the study area, farmers have experienced erratic rainfall and increasing temperature, increasing the number of hot days, an upward shift of snowline, changes in the sprouting, and ripening time of crops (Figure 7). Farmers have started sowing and harvesting earlier by one week to a more than one month that brought changes in the agricultural calendar. Importantly, the increasing temperature has encouraged farmers to cultivate many new vegetables (see Figure 3). Though climate change has provided a suitable 
environment for vegetable cultivation, it is not only the reason for introducing new crops in the study area. Local respondents mentioned the changes as ..."the snow line was much below in the mountains before 30 years which has now shifted up. Also, the rain is now more erratic and untimely (Nima Gurung, $66 \mathrm{M}$ ). Similarly, Maya Magar $(48, \mathrm{~F})$ claims"... before vegetable cultivation was not possible due to low temperature but now the temperature has increased which has helped us in the cultivation of various vegetables. The crops also grow early and the productivity has also improved".

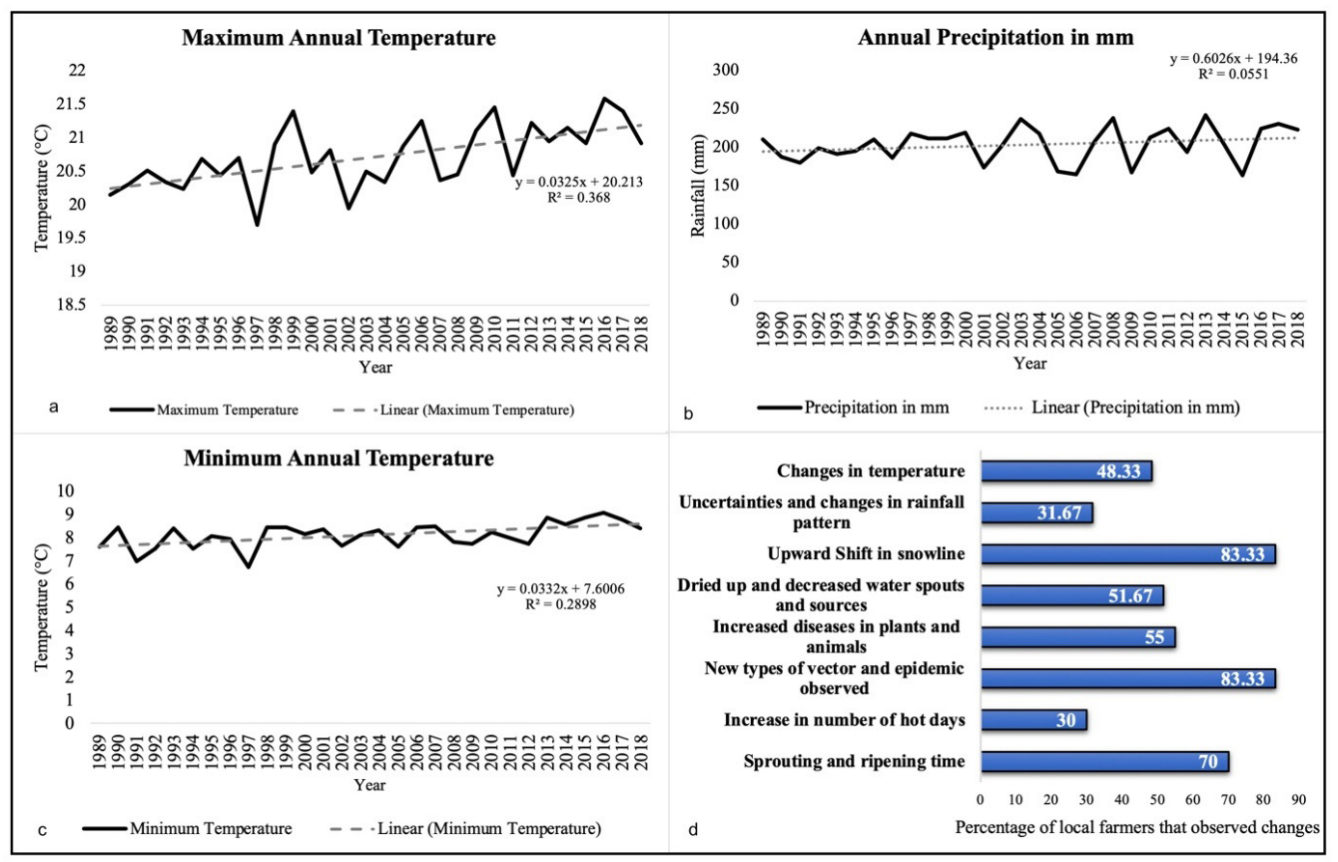

Figure 7: Maximum temperature trend* (a), Minimum temperature trend* (c), Precipitation trend* (b), Changes observed by local farmers due to climate change** (d) Source: *DHM, **Field Survey

\section{Access to market}

Market access has encouraged many farmers of Nepal to shift from cereal crops to commercial crops (Bhatta, Helmuth van Oort, Stork and Baral, 2015; Chapagain, 2006; Dahal et al., 2018; Raut, Sitaula, Aune and Bajracharya, 2011; Sijapti, Bhatti and Pradhan, 2014; Aase and Chapagain, 2017), where a shift from cereal crops to vegetables was due to increased market access. After the construction of roads to Charikot, Singati, and the village, the accessibility to nearby market centers increased. Opening of foreign labor migration and off-farm employment in Kathmandu, local people began to have 
consistent cash flow. It has enabled them to buy food and other supplies from nearby markets. Earlier people from nearby villages used to come to study area to buy potatoes, sheep's wool and bhakari (storage container) made from Himalayan bamboo (Nigalo). Upland potato cultivation has not been lucrative because potato seeds now available in the market and no outsiders visit for it. The livestock market has also been decreased as it is limited within the nearby villages. The decrease in livestock size has resulted in less manure production and declining agricultural productivity. The upland agricultural land abandonment has primarily resulted due to low agricultural productivity.

\section{Change in food habit and crops}

The change in the food habit of local villagers is very recent. The main change in food habits in upland and midland was after the constructions of the road to the district headquarter during 1980 and to Singati which made access to buying rice and other products easier. The main food grains during and before the 1980s were local wheat, maize, millet, and potato. Wheat was consumed from the month of May/June to July/ August as dhido (porridge) or chapatti (bread). Maize was consumed from August/ September to November/December as dhido and millet were consumed from November/ December to March/April as dhido and chapati and also saved for making local beer, especially during feasts and festivals. Potato was consumed all the year round in upper elevation. In the past, people from upper and middle zones walked for two days round trip to take limited white rice that was distributed through cooperatives at the district headquarter. Consuming rice daily was considered to be a social prestige and only a few who had irrigated land at lower elevation could produce and consume it. The highlanders often bartered white rice with potatoes in a ratio 1:2 with lowland people. However, the lowland farmers of the study village stopped cultivating rice after 1990 due to the decline in productivity.

The dependency on rice for food escalated more after the construction of the road from Singati to the study area in 2009. Before rice was only eaten in festivals like Dashain, Sankranti (first day of every Nepali month), and during marriages. However, dhido is now consumed occasionally. According to FGD, 70 percent of households consume rice all the year round. Since rice is not cultivated in the area, farmers have to purchase rice from the nearby market. As such, the consumption of other grains that are cultivated in that area has declined and dependency on the food market has been increased. Combined with increasing income, easy access to rice, and growing distaste for local food among the new generation were the reasons for the decline in cultivation and production of necked barley, barley, and buckwheat in the study area. Millet cultivation has not decreased due to its higher demand for local beer which is also common to other 
parts of Nepal (Sijapti, Bhatti and Pradhan, 2014). Local beer is important in many ritual purposes for indigenous people. Regarding the cultivation of local food, Sarita Gurung $(38, \mathrm{~F})$ claims ".... our family stopped cultivating necked barley, barley and buckwheat for more than six years because we don't like its taste." Chodi Sherpa (46, M) also argues "... my family cultivates millet for making alcohol rather than for grain."

\section{Extension services and training}

Nepal government has initiated different policies to help local farmers to cultivate new crops and improve their livelihood. Different institutions have conducted various projects like vegetable farming training in different parts of Nepal to improve the economic condition of farmers (Upadhyaya, 2000). In the study area, about 17 percent of the respondents have participated in vegetable farming training. The new vegetables and fruits in the study area were mainly introduced through INGOs/NGO's and government projects. A total of 25 farmers from the study village were trained in climate-smart tomato and chili cultivation training (UNDP, 2018). From the household survey, it was found that nearly 10 percent of the respondents have continued vegetable farming after the training. Some of the respondents share its success as "... After training, I started cultivating tomato and mushroom ... Mushrooms have grown without any pest problem but tomato's production declined after a year because of some disease" (Rita Gurung (42, F). Similarly, Sita Sherpa (39, F) shares "... I received vegetable farming training and have been cultivating tomatoes commercially. Tomato was not consumed before 10 years in the village. I made a good profit from it last year (more than 15,000 NPR). I am planning to increase the number of tunnels".

\section{Conclusion}

Major changes in agricultural practice have been observed in Marbu village in the last few decades. Cultivation of a few crops such as barley, buckwheat, rice, bean, and paddy has significantly declined. Many new vegetables and fruit cultivation have started in the village. Several events have taken place within and outside of the villages that have been contributed to changes in the local farming system. Among these, migration, infrastructure development and connectivity, change in food habits, extension services and training, market, and climate change have played the role of major drivers. Flourishing of the carpet industry attracted young laborers to Kathmandu that began to reflect in the upper elevation zone while the opening of foreign employment mainly attracted the young people of middle and lower elevation. The recent infrastructure and hydropower development at the local level attracted laborers from all three zones. Villagers are now attracted to more clean jobs that provide them with regular cash flow. The availability of cash and easy access to the market through roads led 
to an increase in the demand for rice and thus, changes in the food habits of the local villagers. Finally, change in temperature has positively affected the village by creating a suitable environment for the cultivation of new vegetables. However, climate change has also shifted the cropping calendar by almost a month and many farmers are already experiencing early ripening of various crops.

However, the changes in the farming system and how the villagers have adapted to such changes have both positive and negative implications. More than half of the cultivated land has been abandoned which shows the under-utilization of the land resources. It will increase market dependency on food, dairy, and livestock products. Increasing outmigration and declining interest of youth to farming may preserve the flexibility of retention, keeping part of the resources during the time of need, but it can cause a loss of agronomical knowledge. However, the flexibility of alternation of crops and the timing can lead to some innovation in agricultural practices especially of vegetables, commercialization of paper shrubs (lokta/argeli) and dairy products that sustain agriculture of the region.

\section{Acknowledgement}

The fieldwork of the study was funded by the National Natural Science Foundation of China (Grant No. 41761144081), the Strategic Priority Research Program of Chinese Academy of Sciences (Grant No. XDA20040201) and the second Tibetan Plateau Scientific Expedition and Research Program (STEP) (Grant No. 2019QZKK0603).

\section{References}

Aase, T. H., \& Chapagain, P. S. (2017). Organic farmers on the ridge. Climate Change and the Future of Himalayan Farming, 229-266. https://doi.org/10.1093/ oso/9780199475476.003.0008

Aase, T. H., Chapagain, P. S., \& Tiwari, P. C. (2013). Innovation as an expression of adaptive capacity to change in Himalayan farming. Mountain Research and Development,, 33(1), 4-10. https://doi.org/10.1659/MRD-JOURNAL-D-12-

Aase, T. H., \& Chapagain, P. S. (2005). Nepal agriculture in crisis? Studies in Nepalese History and Society, 10(1), 39-56.

Acharya, C. P., Leon-Gonzalez, R. (2014). How do migration and remittances affect human capital investment? The effects of relaxing information and liquidity constraints. Journal of Development Studies, 50:444-460. doi:10.1080/00220 388.2013.866224. 
Aydinalp, C., \& Cresser, M. S. (2008). The effects of global climate change on agriculture. American-Eurasian J. Agric. \& Environ. Sci., 3(5), 672-676.

Barry, R. G. (2008). Mountain weather and climate. New York: Cambridge University Press.

Bhatta, L. D., Helmuth van Oort, B. E., Stork, N. E., \& Baral, H. (2015). Ecosystem services and livelihoods in a changing climate: Understanding local adaptations in the Upper Koshi, Nepal. International Journal of Biodiversity Science, Ecosystem Services \& Management, 11(2), 145-155.

Brown, S., \& Kennedy, G. (2005). A case study of cash cropping in Nepal: Poverty alleviation or inequity? Agriculture and Human Values, 22, 105-116.

Budathoki, N. K. (2017). Climate change: Perceptions, reality and agricultural practice: Evidence from Nepal. Kathmandu: SANDEE.

CBS. (2014). Population monograph of Nepal volume III (Economic demography) . Kathmandu: Central Bureau of Statistics.

Chapagain, P. S., Rai, M. K., \& Paudel, B. (2018). Land use land cover change and its pathways in Sidin VDC, Panchthar district, Nepal. The Geographical Journal of Nepal, 11, 77-94.

Chapagain, P. S. (2006). Involution or evolution? Conceptualizing the changes in farming system of Eastern Nepal. The Himalayan Review, 37, 1-17.

Charmakar, S. (2010). Exploring existing local adaptation practices on potential strategic options to address climate change impact on biodiversity and its dependents of Nepal. Kathmandu: National Adaptation Programme of Action.

Chidi, C. L. (2016). Depopulation and rural land abandonment in the hills of Nepal. SSARSC International Journal of Geo Science and Geo Informatics, 3(1), 1-7.

Choithani, C. (2017) Understanding the linkages between migration and household food security in India. Geographical Research, 55(2):192-205. doi:10.1111/17455871.12223

Dahal, B. M., Raut, N., Gurung, S., Sharma, C. M., Kayastha, R., Shrestha, A., et al. (2018). Changing trends in cultivation practices and adoption of climate adaptive farming in Eastern Nepal. Sustainable Agriculture Research, 7(3), 5262.

Dahal, B. M., Nyborg, I., Sitaula, B. K., \& Bajracharya, R. M. (2009). Agricultural intensification: food insecurity to income security in a mid-hill watershed of Nepal. International journal of agricultural sustainability, 7(4), 249-260. 
Dhakal, S., Sedhain, G. K., \& Dhakal, S. C. (2016). Climate change imapct and adaptation practices in agriculture: A case study of Rautahat District, Nepal. Climate, 4(63), 1-22.

DHM. (2017). Observed climate trend analysis of Nepal (1971-2014). Ministry of Population and Environment, Nepal. Kathmandu: Department of Hydrology and Meteorology.

Ghimire, P., \& Aase, T. H. (2007). Factors affecting farming system in the transHimalayas: A case study of Upper, Manang, Nepal. In R. P. Chaudhary, T. H. Aase, O. R. Vetaas, \& B. P. Subedi (Ed.), Local effects of global change in the Himalays: Manang, Nepal. Kathmandu: Tribhuvan University and University of Bergen.

Guillet, D. (1983). Toward a cultural ecology of mountains: The Central Andes and the Himalayas Compared. Current Antropology, 561-574.

ICIMOD. (2012). Policy and institutions in adaptation to climate change: Case study on tree crop diversity in China, Nepal and Pakistan. Kathmandu: International Centre for Integrated Mountain Development.

Jaquet, S., Kohler, T., \& Schwilch, G. (2019). Labour migration in the middle hills of Nepal: Consequences on land management strategies. Sustainability, 11(5), 1349.

Kafle, A. (2017). Nepal's foreign trade: Present trends. International Journal of Latest Engineering and Management Research (IJLEMR), 02(11), 01-07.

Khanal, N. R., \& Watanabe, T. (2006). Abandonment of agricultural land and its consequences. Mountain Research and Development, 26(1), 32-40.

Khanal, U., Alam, K., Khanal, R., \& Regmi, P. (2014). Implications of out-migration in rural agriculture: A case study of Manapang village, Tanahun, Nepal. The Journal of Developing Areas, 49(1), 331-352.

Lama, S., \& Devkota, B. (2009). Vulnerability of mountain communities to climate change and adaptation strategies. The Journal of Agriculture and Environment, 10. DOI: 10.1353/jda.2015.0012 .

Lamichhane, J., Ranabhat, D., Adhikari, S., \& Dhakal, C. S. (2014). Impact of climate change on wheat production and livelihood of marginalized community in Nawalparasi district of Nepal. Proceedings of the 29th National Winter Crops Workshop (pp. 235-242). Kathmandu: Nepal Agricultural Research Council. 
LRMP. (1986). Land Utilization Report. Land Resource Mapping Project, Kenting Earth Science Canada and Department of Topography. Kathmandu: Government of Nepal.

Manandhar, S., Schmidt-Vogt, D., Perret, S., \& Kazama, F. (2011). Adapting cropping systems to climate change in Nepal: A cross-regional study of farmers' perception and practices. Regional Environmental Change, 11, 335-348.

Martin, G., Martin-Clouaire, R., \& Duru, M. (2013). Farming system design to feed the changing world. A review. Agron. Sustain. Dev., 33, 131-149.

MoE (2010). Climate change vulnerability mapping of Nepal. Kathmandu: Ministry of Environment.

MoF (2019). Economic survey 2018/19. Kathmandu: Ministry of Finance.

MoLE. (2018). Labour migration for employment A status report for Nepal: 2015/2016 - 2016/2017. Kathmandu: Government of Nepal.

PAN. (2009). Temporal and spatial variability of climate change over Nepal (19762005). Kathmandu: Practical Action Nepal.

Paudel, K. P., Tamang, S., \& Shrestha, K. K. (2014). Transforming land and livelihood: Analysis of agricultural land abandonment in the mid hills of Nepal. Journal of Forest and Livelihood, 12(1), 11-19.

Paudel, S., \& Shaw, R. (2016). The relationships between climate variability and crop yield in a mountainous environment: A case study in Lamjung district, Nepal. Climate, 4(13), https://doi.org/10.3390/cli4010013.

Rao, D., \& Parwez, S. (2005). Dynamics of cropping pattern in Sorghum growing states of India. Indian Journal of Agricultural Economics, 60(4), 644-659.

Raut, N., \& Sitaula, B. K. (2012). Assessment of fertilizer policy, farmers' perceptions and implications for future agricultural development in Nepal. Sustainable Agriculture Research, 1(2), 188-200.

Raut, N., Sitaula, B. K., Aune, J. B., \& Bajracharya, R. M. (2011). Evolution and future direction of intensified agriculture in the central mid-Hills of Nepal. International Journal of Agricultural Sustainability, 537-550.

Ray, S. K. (2007). Economics of change in cropping pattern in relation to credit: A micro level study in West Bengal. Ind. Jn. of Agri. Econ., 62(2), 216-231.

Regmi, R., Saha, S., \& Subedi, D. (2017). Geospatial analysis of land use land cover change modeling in Phewa Lake watershed of Nepal by using GEOMOD model. The Himalayan Physics, 6, 65-72. 
Sherpa, R., Ayadi, D. P., \& Pradhan, P. (2015). Overview of climate change: Impact and adaptation in Nepal Himalayas. Climate Alliance of Himalayan Communities (CAHC).

Shreshtha, A., \& Baral, S. (2018). The perception, impact and adaptation methods of farmers of rice based farming system to climate change in Banke district, Nepal. Azarian Journal of Agriculture, 5, 96-102.

Shrestha, R. P., Raut, N., Maung, L., \& Tieng, T. (2018). Climate change adaptation strategies in agriculture: Cases from Southeast Asia. Sustainable Agriculture Research, 7(3), 39-51.

Sijapti, S., Bhatti, M. T., \& Pradhan, N. S. (2014). Climate change impact on water availability, and farmers' adaptation strategies: Case studies from Pakistan and Nepal. Kathmandu: ICIMOD.

Tulachan, P. M. (2000). Mountain agriculture in the Hindu Kush- Himalayas: Trends and sustainability. Growth, poverty alleviation and sustainable resource management in the mountain areas of South Asia (pp. 259-274). Kathmandu: Deutsche Stiftung für internationale Entwicklung German Foundation for International Development.

UNDP. (2018). Climate-smart agriculture for resilience in Dolakha. UNDP Nepal. https://www.np.undp.org/content/nepal/en/home/stories/climate-smartagriculture-for-resilience-in-dolakha.html Accessed 25 December 2019

Upadhaya, M. P., \& Joshi, B. (2003). Plant genetic resources in SAARC countries: Their conservation and management, Nepal Chapter. Agriculture Botany Division. Kathmandu: Nepal Agriculture Research Council.

Upadhyaya, H. K. (2000). Sustainable poverty alleviation and mountain development in Nepal: Status, experience and strategy. In M. Banskota, T. S. Papola, \& J. Richter (Ed.), Growth, poverty alleviation and sustainable resource management in the mountain areas of South Asia (pp. 195-224). Kathmandu: Deutsche Stiftung für internationale Entwicklung German Foundation for International Development.

Yang, X., Khanal, N. R., Koirala, H. L., \& Nepal, P. (2014). People's perceptions of and adaptation strategies to climate change in the Koshi River Basin, Nepal. Kathmandu: ICIMOD. 